\title{
GENDER DIFFERENCES IN ANTIPLATELET THERAPY OF ISCHAEMIC HEART DISEASE
}

\author{
I.A.Zupanets, O.Ye.Zaprovalna*, Ie.F.Grintsov, I.A.Otrishko \\ National University of Pharmacy \\ State Institute "National Institute of Therapy named after L.T.Malaya \\ of the National Academy of Sciences of Ukraine"*
}

Key words: ischemic heart disease; antiplatelet therapy; acetylsalicylic acid; gender differences

\begin{abstract}
The number of data about the gender differences in the course and treatment of cardiovascular diseases is continuously growing. In recent years to prescribe the gender-based treatment becomes more popular. In this publication the results of comparative assessment of the platelet hemostasis activity in men and women (106 patients) by long-term therapy with acetylsalicylic acid (ASA) are presented. According to our data the long-term administration of ASA in a standard dose inhibited the platelet aggregation less effective in females than in males. This effect was also the most prominent in the case of the arachidonate-induced platelet agregation associated with the response to ASA. Thus, in this work the gender differences in respond to ASA monotherapy in ischaemic heart disease (IHD) have been revealed. It can be used for further development of the treatment guidelines with focus on the gender-differentiated therapy. Further investigations in this field are crucial.
\end{abstract}

The cardiovascular diseases (CVD) are the leading cause of death in the world for many centuries already, taking up to 18 million people per year. Annually in Europe more than 4 million people die from CVD complications, it is $47 \%$ of all mortality cases.

For many years the highest mortality rates from CVD are in Eastern European countries, including Ukraine [15].

In Europe in the general mortality structure there are some gender differences: cardiovascular mortality in women is higher than in men (42\% vs 38\%) [6]. In Ukraine this difference is even more significant - $57.2 \%$ vs $42.8 \%$. This fact indicates the unsolved issue of the gender approach to CVD therapy [4].

The first data about the need to consider gender differences in the treatment of CVD appeared more than 10 years ago. In 2004 the American cardiologist association started the programme "Red in Women" (focus on women), and in 2005 the European cardiologist society supported this initiative with the own programme "Women at Heart". The aim of these programmes was introduction of the gender approach to identification and treatment of CVD.

The randomised controlled trials, activities for the primary and secondary prevention of CVD with the focus on the female population were conducted at the state level in the USA and resulted in three-fold decrease of the IHD mortality in women compared to 1980. This result was achieved both by the influence on risk factors and introduction of the active targeted treatment strategy [4].

The Joint British Societies (JBS) in the recently published recommendations for the CVD prevention call for more attention on patients with low and moderate risk. As scientists note, the middle-aged women are often undertreated for prevention of atherosclerosis and

\footnotetext{
I.A.Zupanets - Doctor of Medicine, professor, head of the Department of Clinical Pharmacology and Clinical Pharmacy of the National University of Pharmacy (Kharkiv)
}

O.Ye.Zaprovalna - Candidate of Medicine, senior researcher of the Department of Atherosclerosis and Coronary Heart Disease of the State Institute "National Institute of Therapy named after L.T.Malaya of the National Academy of Sciences of Ukraine" (Kharkiv)

CVD although most of the risk factors are modified most easily and favourably [13].

The number of data about the gender differences in the course and treatment of cardiovascular diseases is continuously growing. In recent years to prescribe the gender-based treatment becomes more popular $[1,7,10,11]$.

The need in the differentiated approach is based on pathogenetic features of the disease associated with gender. For example, hemostatic disorders that are the basis of all cardiovascular events are significantly different in men and women [5]. The specific gender differences in the pharmacokinetics of drugs can make a direct contribution to the effectiveness of treatment [14].

The peculiarities of pharmacodynamics, in particular decrease of activity of some enzymes, can also play a key role in the therapeutic effect and in development of the adverse drug reactions [12].

The gender differences in the use of acetylsalicylic acid (ASA) for the primary prevention in males and females are shown in the current guidelines. Despite some differences, all of them agree that the use of ASA for the primary prevention is recommended only if 
Table 1 older $(\mathrm{p}<0.05)$ and had more often

Demographic and clinical characteristics of patients $(n=106)$

\begin{tabular}{|l|c|c|}
\hline \multicolumn{1}{|c|}{ Characteristics } & Males, $\mathrm{n}=61$ & Females, $\mathrm{n}=45$ \\
\hline Age & $57.61 \pm 7.97$ & $63.16 \pm 9.11$ \\
\hline Smoking & $45(73.8 \%)$ & $13(28.9 \%)$ \\
\hline Genetic predisposition for CVD & $42(68.9 \%)$ & $33(73.3 \%)$ \\
\hline Arterial hypertension & $46(75.4 \%)$ & $39(86.7 \%)$ \\
\hline Diabetes mellitus type 2 & $29(47.5 \%)$ & $30(66.7 \%)$ \\
\hline Ml in anamnesis & $46(75.4 \%)$ & $35(77.8 \%)$ \\
\hline Stable FC II stenocardia & $23(37.7 \%)$ & $18(40.0 \%)$ \\
\hline Stable FC III stenocardia & $31(50.8 \%)$ & $21(46.7 \%)$ \\
\hline
\end{tabular}

potential benefit is greater than risk of hemorrhagic complications.

Practical approaches to the use of ASA for the secondary prevention of IHD in males and females are similar. The background for these recommendations is the absence of gender differences of ASA use in decrease of cardiovascular events as shown in many clinical trials [9].

Thus, the issue of efficacy of antiplatelet therapy in the secondary prevention is not completely solved.

Based on the above the aim of our study was to compare the activity of platelet homeostasis in males and females in the long-term therapy with ASA.

\section{Materials and Methods}

In the study 106 patients with chronic forms of IHD (post-infarct cardiosclerosis, stable stenocardia of the II-III functional class tension) were included. Diagnosis was determined according to the guidelines of the European Cardiologist Society and the corresponding guidelines of the Association of Cardiologists of Ukraine. All patients received standard therapy: ASA (75 mg), statins (10-40 mg of atorvastatin or 10-20 mg of rosuvastatin), beta-blockers (2.5-10 mg of bisoprolol), ACF inhibitors or angiotensin II blockers in the corresponding doses.

All patients included into the study underwent a standard clinical examination: physical examination, measurement of the Body
Mass Index (BMI), analysis of blood lipids: total cholesterol (TC), highdensity lipoproteins (HDL), lowdensity lipoproteins (LDL), triglycerides (TG). To assess metabolic changes the carbohydrate metabolism indicators were measured (fasting glucose, glycosylated hemoglobin). The study of the platelet aggregation was performed using the turbidimetric method. As aggregation inductors ADP was used (the final concentration in the cell was $\left.1 \times 10^{-5} \mathrm{~mol} / \mathrm{l}\right)$, arachidonic acid (the final concentration in the cell was $1 \mathrm{mmol} / \mathrm{l}$ ). The complete blood count was carried out on a MS-4 No. 3B0435 hematological analyzer (France). Among the results obtained the platelet count, as well as the mean platelet volume (MPV), platelet dispersion width (PDW) and plateletcrit (Pct) were assessed.

All data were assessed using statistical software package Excel for Windows and STATISTICA. For quantitative parameters the hypothesis about the normal distribution law was tested by the asymmetry index.

\section{Results and Discussion}

The comparative analysis of demographic and clinical characteristics of males and females included into the study (Table 1) showed the following. When comparing the severity of disease (the number of old myocardial infarctions (MI) and severity of stenocardia were not significantly different in the groups) females were diabetes mellitus type 2 (DM2). Genetic predisposition and the presence of arterial hypertension were not significantly different. At the same time, males were 3 times more often past smokers.

Significant gender differences were observed when assessing clinical and biochemical characteristics (Table 2). In females BMI and the fasting glucose level were higher than in males $(\mathrm{p}<0.05)$, it is probably related to higher proportion of patients with DM2 in the female group.

When assessing lipids in the blood the parameters between groups were not significantly different, excluding the level of highdensity lipoproteins.

The analysis of the thrombocytogram parameters was not also shown significant differences.

The aggregative capacity of platelets in groups had significant differences. The arachidonate-induced aggregation was significantly higher in women both by the total index of the platelet aggregation (TIPA) and by the speed of aggregation $(\mathrm{p}<0.05)$. The ADP-induced aggregation of platelets was not significantly different from TIPA, but had a higher speed in females.

According to our results the long-term administration of ASA in a standard dose inhibited the platelet aggregation less effective in females than in males. This effect was also the most prominent in the case of the arachidonateinduced platelet aggregation associated with the response to ASA administration.

In this work the indicators of platelet hemostasis without antiplatelet therapy have not been studied due to impossibility to withdraw these drugs in patients with coronary artery disease for ethical reasons.

Despite the fact that modern guidelines of IHD treatment do not include special tactics for prescribing medicines differentiated by gender the possible mechanisms 
Table 2

\section{The main clinical parameters of the patients included into the study $(M \pm \delta),(n=106)$}

\begin{tabular}{|c|c|c|c|}
\hline Parameters & Males, $\mathrm{n}=61$ & Females, $n=45$ & $\mathrm{p}$ \\
\hline $\mathrm{BMI}, \mathrm{kg} / \mathrm{m}^{2}$ & $29.71 \pm 2.34$ & $31.45 \pm 3.46$ & $<0.001$ \\
\hline Fasting glucose, $\mathrm{mmol} / \mathrm{l}$ & $6.72 \pm 2.71$ & $7.76 \pm 3.04$ & 0.011 \\
\hline $\mathrm{HbA}, \%$ & $6.08 \pm 1.48$ & $6.54 \pm 1.49$ & 0.084 \\
\hline $\mathrm{TC}, \mathrm{mmol} / \mathrm{l}$ & $4.61 \pm 1.34$ & $4.94 \pm 1.29$ & 0.133 \\
\hline $\mathrm{LDL}, \mathrm{mmol} / \mathrm{l}$ & $2.56 \pm 1.08$ & $2.79 \pm 0.88$ & 0.132 \\
\hline $\mathrm{HDL}, \mathrm{mmol} / \mathrm{l}$ & $1.15 \pm 0.31$ & $1.27 \pm 0.32$ & 0.021 \\
\hline $\mathrm{VLDL}, \mathrm{mmol} / \mathrm{I}$ & $0.97 \pm 0.85$ & $0.78 \pm 0.37$ & 0.573 \\
\hline $\mathrm{TG}, \mathrm{mmol} / \mathrm{l}$ & $2.14 \pm 1.80$ & $1.75 \pm 0.81$ & 0.683 \\
\hline \multicolumn{4}{|c|}{ Parameters of the platelet aggregation } \\
\hline TIPA $_{\text {ADPr }} \%$ & $59.69 \pm 18.33$ & $63.90 \pm 21.07$ & 0.156 \\
\hline Speed of $P A_{A D P}$ unit/min & $0.13 \pm 0.08$ & $0.17 \pm 0.06$ & 0.014 \\
\hline TIPA $_{\text {arach. }} \%$ & $11.39 \pm 15.06$ & $15.76 \pm 17.77$ & 0.046 \\
\hline Speed of $P A_{a r a c h}$, unit/min & $0.08 \pm 0.08$ & $0.10 \pm 0.05$ & 0.027 \\
\hline \multicolumn{4}{|c|}{ Parameters of the thrombocytogram } \\
\hline Platelets, $10^{9} / \mathrm{I}$ & $181.88 \pm 58.84$ & $187.69 \pm 43.26$ & 0.281 \\
\hline MPV, fl & $8.75 \pm 7.17$ & $8.01 \pm 0.66$ & 0.963 \\
\hline PDW, \% & $10.40 \pm 3.29$ & $11.05 \pm 3.02$ & 0.493 \\
\hline Pct, units & $0.14 \pm 0.05$ & $0.17 \pm 0.13$ & 0.264 \\
\hline
\end{tabular}

in results of CVD treatment in males and females are continuously discussed.

One of the possible causes is the low efficacy of antiplatelet the- rapy of CVD in women. The results of some studies show the increaprevalence of ASA-resistance in women [18], but they are not supsed reactivity of platelets and higher ported by the results of other studies $[10,21,29,30]$.

While comparing the effect of ASA high dose (81 mg per day) on platelets of the healthy people of the middle age (females with IHD genetic predisposition and males) Becker et al. revealed the high initial reactivity of platelets in females [9]. Further administration of ASA decreased the platelet reactivity in males and females almost equally. But after ASA administration in females the platelet reactivity was higher due to the higher primary level. Increase of the dose (up to $325 \mathrm{mg}$ ) did not overcome this inequality [8].

CONCLUSIONS

1. There are gender differences in respond to ASA monotherapy in IHD. The residual platelets reactivity in females when using ASA is significantly higher than in males. This can impact on the disease course and outcomes.

2. Insufficiency of the basic knowledge in gender differences in treating CVD requires further studies on this issue. Development of the treatment guidelines with focus on the gender-differentiated therapy is crucial.

\section{REFERENCES}

1. Барна О.Н.//Новости медицины и фармации. -2009. - №274. - Режим доступу: http://www.mif-ua.com/ archive/article/8400.

2. Волков В.И., Запровальная О.Е. // Новости медицины и фармации. - 2011. - №368. - С. 53-59.

3. Волков В.И., Строна В.И., Запровальная О.Е. // Здоров'я України. - 2015. - №3. - С. 14-15.

4. Мітченко О.І. // Здоров'я України. - 2015. - Кардіологія (тем. номер). - С. 20-21.

5. Ткачева О.Н. // Здоров'я України. - 2011. - С. 13.

6. Юренева С.В., Ильина Л.М., Мычка В.Б. // Эффективная фармакотерапия. - 2011. - №13. - С. 32-37.

7. Adelman E.E., Lisabeth L., Brown D.l.// Medscape Cardiol - 2011. - Pежим docmyny: http://www.medscape.org/ viewarticle/742845.

8. Antithrombotic Trialists' (ATT) Collaboration. Aspirin in the primary and secondary prevention of vascular disease: collaborative meta-analysis of individual participant data from randomised trials // Lancet. 2009. - Vol. 373. - P. 1849-1860.

9. Becker D.M., Segal J., Vaidya D. et al. // JAMA. - 2006. - №295. - P. 1420-1427.

10. Bittner V. // J. Am. Coll. Cardiol. - 2009. - Vol. 54, №25. - P. 2374-2375.

11. Black H.R., Gulati M. // Medscape Cardiol. - 2015. - Режим docmyny: http://www.medscape.com/ viewarticle $/ 849508$

12. Cotreau M.M., von Moltke L.L., Greenblatt D.J. // Clin. Pharmacokinet. - 2005. - Vol. 44. - P. 33-60.

13. Eikelboom J.W., Hirsh J., Weitz J.I. et al. // Circulation. - 2002. - Vol.105. - P. 1650-1655.

14. Meibohm B., Beierle I., Derendorf H. // Clin. Pharmacokinet. - 2002. - Vol. 41. - P. 329-342.

15. Nichols M., Townsend N. European Cardiovascular Disease Statistics, 2012 edition. - Pежим доступy: http://www.escardio.org/The ESC/Initiatives/EuroHeart/2012-European-Cardiovascular-Disease-Statistics 
ГЕНДЕРНІ ОСОБЛИВОСТІ АНТИТРОМБОЦИТАРНОЇ ТЕРАПІЇ ПРИ ІШЕМІЧНІЙ ХВОРОБІ СЕРЦЯ

І.А.Зупанець, О.Є.Запровальна*, Є.Ф.Грінцов, І.А.Отрішко

Національний фармацевтичний університет, дУ «Національний інститут терапї̈ ім. Л.Т.Малої НАМН України»*

Ключові слова: ішемічна хвороба серця; антитромбоцитарна терапія; ацетилсаліцилова кислота; гендерні відмінності

\begin{abstract}
У зв'язку з постійно зростаючою кількістю даних про важливість специфічних гендерних відмінностей між захворюваннями серцево-судинної системи в останні роки призначення лікування з урахуванням гендерних особливостей стає все більш затребуваним. У даній публікації представлені результати порівняльної оцінки активності тромбоцитарного гемостазу у чоловіків і жінок (106 пацієнтів) при тривалій терапії ацетилсаліциловою кислотою. За нашими даними тривалий прийом АСК у стандартному дозуванні чинив менший вплив на агрегаційну здатність тромбоцитів у жінок, ніж у чоловіків, причому це було найбільш виражено при арахідонат-індукованій агрегації тромбоцитів, тобто могло бути безпосередньо пов'язане з відповіддю на АСК. Таким чином, зафіксовані гендерні відмінності у відповідь на монотерапію АСК при IXС, що обумовлює необхідність проведення подальших досліджень із зазначеної проблеми з можливою подальшою розробкою диференційованих за гендерною ознакою стандартів лікування.
\end{abstract}

\title{
ГЕНДЕРНЫЕ ОСОБЕННОСТИ АНТИТРОМБОЦИТАРНОЙ ТЕРАПИИ ПРИ ИШЕМИЧЕСКОЙ БОЛЕЗНИ СЕРДЦА И.А.Зупанец, О.Е.Запровальная*, Е.Ф.Гринцов, И.А.Отришко Национальный фармацевтический университет, ГУ «Национальный институт терапии им. Л.Т.Малой НАМН Украины»*
}

Ключевые слова: ишемическая болезнь сердца; антитромбоцитарная терапия; ацетилсалициловая кислота; гендерные различия

В связи с постоянно возрастающим количеством данных о важности специфических гендерных различий между заболеваниями сердечно-сосудистой системы в последние годы назначение лечения сучетом гендерных особенностей становится все более востребованным. В настоящей публикации представлены результаты сравнительной оценки активности тромбоцитарного гемостаза у мужчин и женщин (106 пациентов) при длительной терапии ацетилсалициловой кислотой. По нашим данным длительный прием АСК в стандартной дозировке оказывал меньшее влияние на агрегационную способность тромбоцитов у женщин, чем у мужчин, причем это было наиболее выражено при арахидонат-индуцированной агрегации тромбоцитов, т.е могло быть непосредственно связано с ответом на АСК. Таким образом, зафиксированы гендерные различия в ответе на монотерапию АСК при ИБС, что обусловливает необходимость проведения дальнейших исследований по указанной проблеме с возможной последующей разработкой дифференцированных по гендерному признаку стандартов лечения.

Address for correspondence:

Received in 20.10.2015

2a, Postyshev av., 61039, Kharkiv, Ukraine.

Tel. (50) 953-95-88. E-mail: zaprovalna@mail.ru.

State Institute "National Institute of Therapy named after

L.T.Malaya of the National Academy of Sciences of Ukraine" 